\title{
Contemporary Czech Shamanism: A Case Study of Ritual Practice and Healing
}

\author{
Helena Dyndová
}

DOI: 10.21104/CL.2020.2.02

\begin{abstract}
The article presents an overview of contemporary Czech shamanism based on field research into Czech shamanic communities that the author has been conducting since 2017. Despite the specific Czech distrust of 'religion' and 'formalized ritualization' in general, shamanism enjoys considerable popularity. Particular attention is paid to the concept of illnesses and shamanic treatment. It is argued that the shamanic 'action approach' to human adversity offers a relatively broad and attractive explanation as to what is experienced and performed during shamanic ritual. The second part of the paper is dedicated to shamanic ritual, i.e. the paraphernalia, ritual set and setting that create the space for ritual practice and also a safe-space for spontaneous communitas and the participant's own understanding of this psychotherapeutic and religious experience. The final part examines the specifics of contemporary Czech shamanism in the pervasive discourse of modern western spirituality.
\end{abstract}

\section{Key words}

contemporary shamanism, neoshamanism, shamanic ritual, shamanic healing, shamanic healing ritual, modern western shamanism

\section{Acknowledgment}

This paper was written as part of the project SVV 260418 "Krize racionality a moderní myšlení", subproject "Medvědi, lišky a jaguáři: religionistickoantropologická analýza podob současného městského neošamanismu" carried out at Charles University in Prague within the framework of specific university research in 2017.

\section{Contact}

Mgr. Helena Dyndová, Charles University, Faculty of Arts, Department of Philosophy and Religious Studies, nám. Jana Palacha 2, 11638 Prague, Czech Republic; e-mail: helena.dyndova@gmail.com.

\section{Jak citovat / How to cite}

Dyndová, Helena. (2020). Contemporary Czech Shamanism: A Case Study of Ritual Practice and Healing. Český lid 107, 149-166. doi:http://dx.doi. org/10.21104/CL.2020.2.02 
In 2017, it was exactly twenty years since the publishing of Shamanic Performances on the Urban Scene (1997), the ground-breaking study on modern western shamanism by Galina Lindquist. This was also the year I started conducting field research among contemporary Czech shamans. This article methodologically follows anthropological studies which are dedicated to current forms of contemporary European shamanism such as Jakobsen (1999), Lindquist (2004), Wallis (2000 and 2003), Bužeková (2010), Lombardi (2010) and Wilson (2013) and sets out to map the Czech shamanic milieu with a focus on shamanic practice.

Simultaneously, the paper attempts to make up for the unfortunate lack of academic papers on shamanism in the Czech Republic by offering an anthropological perspective. Scholars who have studied Czech shamanism in chronological order are: Dušan Lužný (1994), Zdeněk Vojtíšek (2004 and 2007), partly Matouš Vencálek in his articles related to paganism (2017) and Tatiana Bužeková (2010 and 2019) in Slovakia.

The objectives of this article are to investigate how contemporary shamans employ the key concept of illness and healing and how shamanic ritual practice helps participants of shamanic sessions on their spiritual journey. Thus, this article interweaves the inseparable topics of shamanic treatment and ritual, as demonstrated in my respondents' testimonies.

The article is structured as follows: The first part is dedicated to the methodological approach employed, while the second briefly summarizes the Czech religious specifics which situate contemporary Czech shamans on the current religious scene. Following a short reflection on the discursive similarities between contemporary shamanism and modern western spirituality - which some scholars continue to call the "New Age"1 - I will proceed with the concepts of health and illness, the definitions of which in the shamanic worldview are much broader and more inclusive than those of western medicine. I will focus on how my respondents explained the concepts of illnesses, misfortune, and strokes of fate. This will be followed by a section dedicated to collective shamanic rituals, to the set and the setting during the shamanic sessions. The focus of attention will be on the power of ritual performance, the nexus with the legacy of ancient cultures, communal sharing, and the psychotherapeutic effect.

1 The term 'New Age' refers to Wouter Hanegraaff's 'New age sensu lato', as a complex movement including channeling, healing and growth movements, neopaganism, witchcraft, transpersonal psychology, astrology etc. (1996: 103). Although, there is a serious question over whether or not this terminology, due to its breadth, is not just an "epistemic blackhole", this text uses the term 'New Age' as a shortcut to these above-mentioned complexes of spiritual/ religious practice. For a discussion, see Crockford (2010: 153). 
In the final part, I will argue that contemporary Czech shamanism is a rather eclectic and inclusive system of beliefs. In spite of many similarities to the prevailing 'New Age' movement on the discursive level, I will try to articulate its significant features.

\section{Research introduction}

Thanks to the financial support of my faculty, ${ }^{2} \mathrm{I}$ was able to spend two years conducting field research in Czech shamanic communities by participating in their sessions and seminars. Without this institutional support, it would not have been possible, since these seminars are usually very expensive: A weekend session costs around $€ 150$, which is around $20 \%$ of the average Czech monthly salary, according to the Czech Statistical office (cf. Lindquist 1997: 18 or Jakobsen 1999: 194).

During this time, I visited six separate locations and shamanic groups, some of them only once, some of them repeatedly, in order to complete and compare previously acquired data. Most of the seminars (five out of six) were held in the capital Prague and one location was in the countryside, in a homestead where the shaman lived. The majority of the attendees of the courses were over thirty years old (younger adults were less likely to be able to afford them), and both genders were equally represented (with a slight prevalence of women). The number of participants in the seminars varied from six (minimum) to twenty-five (maximum).

The field research was designed to map the practices of shamans who were influenced by North American or Eurasian shamanism, both traditional (Lakota, Evenki) and reconstructed (Celtic shamanism, Harner's shamanism). The ayahuasca scene, which works with Latin American shamanic spirituality, was omitted intentionally, as the Czech anthropologist Miroslav Horák is already in the process of conducting long-term research among these communities (Horák - Vosáhlová 2016; Horák 2017).

In addition to the participant observations in seminars, which took place over a two-year period, I held many informal interviews. Later on, when I got to know both the professional shamans and regular participants of shamanic courses, I conducted semi-structured interviews, which served as the primary basis for my argumentation in this article.

Out of respect for my informants, I decided to avoid the slightly pejorative word 'neo-shamanism'. In shamanic communities, this term is perceived as direct academic reference to their alleged 'inauthenticity'. There-

2 Faculty of Arts, Charles University, Prague, Czech Republic. 
fore, I will use the terms 'current (Czech) shamanism' or 'contemporary (Czech) shamans' throughout the article. ${ }^{3}$

Bearing in mind the difficulties with academic definitions of shamanism, I eventually decided to take the word 'shaman' in an emic sense and to consider shamans to be people who claimed to be shamans, people who worked in 'a shamanic way' or people who 'walked a shamanic path'. I also took it seriously when a shaman's followers or course attendees confirmed shamanic status of the course leaders, even though many of these leaders didn't feel themselves to be 'real shamans'. ${ }^{4}$

The list of my informants can be seen in Table 1. There were three men and three women, all of them long-term participants who had embraced shamanic practices in their everyday lives. All of them were between 30 and 50 years old, four of them had a university degree and five of them worked in middle-class occupations, only one was a storekeeper. There were two 'professional shamans' who earned money entirely from shamanic practices such as providing seminars, healing therapies, sweat lodges etc. One shaman was a certificated FSS shaman (see the section on Czech religious specifics), the second one had elaborated his own 'shamanic path'. All of them accepted the focus of my research and made sincere efforts to help me find answers, for which I am grateful.

\begin{tabular}{|l|l|l|}
\hline \multicolumn{3}{|l|}{ Table 1 List of informants } \\
\hline Informant & Occupation & Gender \\
\hline A & Freelancer & Female \\
\hline B & Jungian psychotherapist & Female \\
\hline C & Elementary school teacher & Female \\
\hline D & Storekeeper & Male \\
\hline E & Shaman & Male \\
\hline F & Shaman (FSS) & Male \\
\hline
\end{tabular}

3 According to Kocku von Stuckrad and Robert Wallis, leading researchers on modern shamanism, there is no such thing as 'traditional' and 'neo'shamanism. For a discursive analysis of shamanic terminology, see Stuckrad (2015:160-176) and see Robert Wallis (2003: 30) for a critique of the term 'neo-shamanism'. For a discussion overview on the definition of 'shaman' and 'shamanism', see the excellent article by Lars Kirkhusmo Pharo (2011).

4 Compare to Crockford's assumption that: "By trying to resist modernity, shamanism becomes modernity par excellence. Shamanism is deemed inauthentic because modernity in the industrialised West is deemed inauthentic" (Crockford 2010: 142). 


\section{Czech religious specifics}

Before the main line of argumentation, it is necessary to give a brief overview of the position of shamanism within the context of the religious specifics in the Czech environment. According to sociological studies, Czechia is considered to be 'the most atheist country' in the whole of the Western world. For complex historical reasons (rooted in the 19th century), the Czech nation carries deep inside its culture a great distrust of institutionalized forms of religion (Nešpor - Nešporová 2009), as evidenced by the 'dominant' Catholic Church having only $10 \%$ of the population as adherents in 2011 (Hamplová 2013).

In contrast to neighboring Poland, Roman Catholicism never functioned as a source of national identity; in the time of the national revival in the 19th century, it was even considered to be a symbol of cooperation with the ruling Austro-Hungarian Empire and its oppression. Mainline Protestantism failed to fill in the gap in the Czech religious environment at the beginning of the 20th century after World War I; and it was mainly the forty years under the communist regime (1948-1989) that sealed this universal distrust by creating a cold, or even hostile environment for institutionalized forms of religion: by means of defamations, bans, and prosecutions.

With the disintegration of the Soviet Union in the 1990s, the Czech Republic opened its gates to the overwhelming influence of western goods, economics, and religious movements. Since then, as regular sociological studies show, the actual number of nominal Czech 'atheists' has been decreasing, while there has been a massive growth in the number of 'spiritual seekers' searching for their own individual mixture of religiosity (Hamplová 2013: 11-23).

When considering contemporary shamanism, which has become very popular on the proliferating new spiritual market, we always have to take into account the 'normative' power of modern western spirituality's discourse (Stuckrad 2015: 3-14). The spirituality and philosophy stressed by the 'New Age' movement (with the emphasis on ecology, self-development, inner harmony...) provides umbrella terminology for other spiritual branches and, therefore, they unify the discourse of the current Czech religious environment to a significant extent (Hanegraaff 1996: 94-104).

In the case of the contemporary shamans, the combinations and the variety of spiritual techniques co-practiced with shamanism were rather frequent. Moreover, my respondents often used 'New Age' terminology while speaking about their shamanic experience; for instance, the power animal, the guide and spiritual helper in the "Lower world", was commonly perceived as an embodiment of their own hidden inner energy. 
Contemporary shamans also share a common rhetoric of distrust and alienation with regard to institutionalized forms of religion, as represented by the Catholic Church, since in their view 'being religious' equals 'having religious experiences' (Kostićová 2019). One shaman was allegedly told by the spirits that the purpose of the existence of the Catholic Church is to prevent the spiritual transformation of humankind. So, in the best-case scenario, contemporary Czech shamans consider some Christian techniques to be shamanic, noting that Christians do not use the full potential of the spiritual work that is in play. As one of my informants put it: "And what about holy water? Water purification is a shamanic technique, isn't it?" (Informant B, 13/10/2017)

Interestingly enough, shamanism remains popular with a considerable number of 'spiritual seekers' despite the fact that there is no indigenous Czech shamanic tradition and there is no historical evidence of archaic shamanism on the territory of the Czech Republic, unlike in Iceland and Sweden, where Lindquist's (1997) and Jakobsen's (1999) research was conducted. And even the putative (but, historically, not entirely misleading) Celtic identity of many Czech sympathizers of modern western spirituality remains, in the end, quite weak and unconvincing.

As for Harner's famous Foundation for Shamanic Studies (FSS), which propagated its version of modern western shamanism called 'core shamanism' throughout the world, there is no shaman with the FSS gold (final) certificate resident in Czechia. ${ }^{5}$ Hence, even though professional Czech shamans are familiar with Harner's 'core shamanism', they are often self-made men (and women) who work with a diversity of spiritual sources and create their own unique eclectic teaching, inspired by books on traditional shamanic societies, Far Eastern spiritual concepts (such as karma, tantra or aura) and also by the Slavic polytheistic roots and beliefs in local mythological beings, such as nymphs (víly) or imps (skř́tci).

Keeping in mind the characteristics of current Czech shamanism, let us now turn to the most prominent topic of shamanism: human adversity and illness.

\section{The shamanic concept of illness}

According to my field research, the most significant part of shamanic work is dealing with human suffering, illness and adversity. This feature is in accordance with the popular western image of the shaman, widely popularized by Michael Harner (Exnerová 2018).

5 In contrast to Slovakia, where there are at least two certificated shamans (Vojtíšek 2007). 
Shamanic treatment encourages a holistic understanding of illness with respect to one's own autodiagnosis and the interpretation of the therapy's efficiency that is experienced during a shamanic healing ritual. Shamans mostly treat illnesses and sicknesses in the sense of Arthur Kleinman's explanatory model, where 'illness' stands for perceiving, living with and responding to symptoms, disability and 'sickness' for "the understanding of a disorder in its generic sense across a population in relation to macrosocial (economic, political, institutional) forces" (Kleinman 1962: 3-8).

Consequently, in current Czech shamanism, illness and sickness is perceived within a somewhat broad definition: from mental to physical diseases, from broken and non-functional relationships to feelings of emptiness. All of the above-mentioned kinds of suffering focus on shared points of perceiving an imbalance with this world. As my informants repeatedly claimed, whatever disturbs personal integrity and the feeling of wholeness is classified as illness.

Therefore, contemporary shamanism deals with any kind of 'disharmony' or 'disconnection with cosmic energy', as the real cause of any illness, and leaves a huge space for potential change. As one shaman posits, "What does illness mean from the shamanic perspective? Illness is everything that prevents you from living a happy and joyful life. [...] Because the norm is when you are healthy. [...] Which means that if you can't find a job, it's an illness and it can be cured. If you can't find your soulmate, it's an illness and it can be cured..." (Informant E, 22/05/2017).

Current shamanism is endowed with its own theodicy, with its own teachings about the roots of adversities, and hence it is able to provide together with the client - an explanation of the causes of all illnesses and all other problems with which it subsequently works.

The assumption goes as follows: if the world is one giant interwoven network connected with 'cosmic energy', the logical conclusion of this worldview is that evil cannot exist. Or, to be more precise: chaotic, jeopardizing, endangering, treacherous and groundless evil does not exist. Obviously, there are mean people who desire to harm us and use their power against us (witches and sorcerers) (Informant D, 22/05/2017), there are diseases that make use of our weaknesses and need to be forced out, and there are even accidents that can be the result of one's karma (a classic macrosocial explanation). But their nature is slightly different from 'evil'. Since everything in this world is related to everything in terms of energy, evil is perceived as a rather destabilizing element in the first place. Accordingly, misfortune and illness cannot be excluded from this system or set apart (Hanegraaff 1996: 276-277). 
The soul's destabilization and disintegration or loss, and emotional, spiritual or physical imbalance all take the form of exhaustion, depression or other adversities. "Illness is mostly some kind of energy blockage. Even a broken leg could be an energy blockage. It means that you are not living in harmony and because the energy can't flow without hindrance, it causes an energy blockage materializing itself in an illness" (Informant A, 31/ 10/2017).

Within the frame of this compelling logic, all misfortune can be explained either on the biological, psychological, social, or even on the spiritual, cosmic level. The discovery of absolute meaningfulness naturally brings a huge commitment to this awareness and is both liberating and very demanding at the same time.

From the perspective of current shamans, on the one hand, the source of almost every evil and misfortune can be cured but, on the other, as a result of this belief, everybody is responsible for their own happiness. In other words, each individual is responsible for their own health. As one of my informants articulated it persuasively, "It's not your fault that you have an illness, but you have a responsibility to do something about it. [...] Some steps lead to recovery and others lead to illness" (Informant B, $13 / 10 / 2017)$.

We are always responsible for our lives to some degree, but in the current shamanic worldview, moreover, we are in full control of our health and happiness, because "from the shamanic perspective, there is nothing like an incurable disease" (Informant F, 22/04/2017). In addition to this, if we go off the rails, our soul will give us an indication. And if we don't heed these warnings and continue to live wilfully, our soul will strike us with intensifying signs that we are doing something wrong. "Illnesses are like indicators, like a signpost saying: 'Not this way!' [...]. When you are walking in the wrong direction, like completely wrong, then the illnesses often get increasingly severe - or the accidents. It is going to escalate" (Informant B, 13/10/2017).

Illnesses and misfortunes are thus firstly perceived as curable problems and secondly as a chance to notice one's own behavior and thus as an opportunity to change it - because everybody can have a firm hand on the tiller. The suffering works as an accelerator, as a purifying but dispensable element (Informant B, 13/10/2017).

In this 'action', cause-and-effect approach to suffering, everybody can (and is even obliged to) relieve themselves of it, and, therefore, the most important thing is to work therapeutically on the body, mind and soul. "It can be my mind, my soul or my spirit, if we are talking about spiritual- 
ity, or my body. If I cultivate all these aspects with more or less the same effort in order to achieve a balance between them, I should be able to live a high-quality life" (Informant D, 15/10/2017).

Thus, contemporary shamans do not condemn western biomedicine due to its highly specialized efficiency, but, at the same time, they stress that it ignores other important aspects of illness and has certain limits (e.g. in dealing with psychosomatic or chronic illnesses). Similarly, they do not reject psychotherapeutic work, which is considered a supportive tool of self-knowledge and spiritual growth.

Moreover, contemporary shamans see little significant difference between shamanism and psychotherapy in dealing with emotions and human potential. Perhaps the only difference lies in the fact that with psychotherapy, the patient is reliant on the therapist's long-term help, while in shamanism a person can follow their own advice and help themselves immediately. "I don't see any significant difference between psychotherapy and shamanism when you descend into your Self and seek the cause. You are just releasing the energy block, whether you find it [i.e., the cause] on a shamanic journey or with a therapist" (Informant A, 31/10/2017).

While the apprentices of contemporary shamans often construe private shamanic ritual as therapeutic work on themselves and use shamanic techniques to discover their inner selves, professional shamans heal mostly by means of the spiritual world. They assume that a change in the spiritual world causes an effect in this world, in the bodies and minds of their clients. In the shamanic trichotomy of body-mind-soul, professional shamans predominantly heal the soul. In the shamanic perspective, the soul may be broken, some parts of it may even be lost or gone, and it is the shaman's calling to 'travel' to the spiritual world in an 'altered state of consciousness' (Harner 1980) and put their clients right.

Since no one can treat his own soul, ritual comes into play as the salient element of current Czech shamanic practice, as a tool to enter the world of shamanic healing in the broad sense referred to above. The ritual may be in the form of an individual session or a collective event. I would like to confine myself to the collective ritual, as it is the most frequently performed technique when encountering shamanic seminars.

\section{Ritual practice}

Phenomenological analysis and the symbolic power of shamanic seminars

Despite the fact there are many different shamanic courses, the places where the rituals are held are surprisingly similar. Even the schedules of the shamanic seminars are quite similar. Hence, wary of the traps of such general- 
izations, in order to paint a more detailed picture, I decided to describe some kind of a Weberian ideal type (Weber 1914), i.e. a prototype of a shamanic session which aims to delineate the repeating patterns in shamanic rituals and ritual places and to create a stone marker for the subsequent analysis.

Where does this 'model' shamanic seminar take place? Shamanic workshops or seminars are typically held in rented rooms or school gyms. The minimalist aesthetics of these settings, i.e. bare walls, wooden floor, and no furniture, is also repeated in those rooms reserved exclusively for shamanic seminars. This seems to be for pragmatic reasons - it's more convenient to have a place where the participants of the seminar can move around in an empty, uncluttered space. However, the organisers' reluctance to adapt the environment to its purpose is noteworthy. (I suppose the lack of visual symbolism balances the importance of the participants' imagination, an observation which will be discussed below.)

At this point it is necessary to take into account the fact that contemporary shamans gain their symbolic potential by constantly referring to 'original-inhabitants-of-Mother-Earth' symbolism. From the perspective of contemporary shamans, these 'mythical' shamanic nations lived in harmony with nature, in a community with themselves and with others, which is also one of the goals of current shamanic practice: to live in harmony with everybody and everything.

This wishful connection to ancient shamanic rituals is permanently enacted by the choice of ritual settings and tools: contemporary shamans sit on the ground in a circle during sessions, reminding the participants of equality and unity. They use the smoke ritual to purify themselves, choosing 'indigenous herbs and plants' such as cedar bark, the leaves of white sage and powdered copal, even though they have to buy them because the climate is not suitable for these plants in Czechia. In the middle of the circle of participants, there is an altar. These altars always appear to be rather improvised, and their aesthetics tend to be austere. Various artefacts are usually arranged around the central point, which is represented by a candle. They symbolically refer to 'traditional shamanism' and, as such, they are usually furs, pelts, antlers, feathers, stones, conches and seashells.

The ritual part demonstrates its connection to its indigenous roots by employing ethnographically described shamanic rituals, such as, for instance, the smoke ritual, shamanic drumming, journeys to other worlds or the accompanying of dead souls. The primus inter pares status belongs to the shaman who leads the participants through the whole seminar. These seminars usually start by lighting a central candle on the altar and by purifying the space with the above-mentioned 'original, indigenous' herbs. At that point, all the participants introduce themselves, giving the names by 
which they want to be known, their occupations, where they come from and why they are attending the seminar.

After this, the course of the seminar varies according to whether it is a basic seminar where participants learn the basics of shamanic journeying and seek their power animal, or whether it is some sort of advanced seminar, where they, for instance, learn how to heal a lost soul or guide the dead souls to the world beyond.

All the seminars and sessions I attended had the same structure: in the first part, the shamans gave lectures that provided the theoretical background and illustrated the connection to traditional shamanism. In the second part, the shaman gave participants instructions on how the ritual should proceed, or, alternatively, the participants first tried the "trial version" of the ritual. The third part was dedicated to the actual performance of the ritual. The fourth and final part consisted in communal sharing.

\section{Performing the shamanic ritual}

The pivotal part of every seminar was the practical part, which was generally ritualistic - whether the participants were collectively journeying into the "Lower world" in order to heal the client, trying to summon their own defensive energy shields, searching for their power animal, performing its dance, participating in a sweat lodge ceremony or participating in shamanic drumming or healing ritual. ${ }^{6}$

For the shamans and participants of shamanic sessions, the ritual constitutes a binding framework, "the framework for an encounter between people and spirits" (Informant F, 22/04/2017). Moreover, the ritual allows for acting "consciously and with attention" (Informant A, 31/10/2017). Some of the supporting aspects that strengthen the ritual's efficiency are the number of people attending the ritual, the position of the altar with respect to the four cardinal points, whether it is day or night time and the positioning of men and women during the ritual. ${ }^{7}$ Another important fea-

6 See Lindquist's description of the "Spirit Boat" healing ritual (1997: 95-97).

7 The connection between the position of the altar and the four cardinal points is rather complicated. Some shamans place great emphasis on the symbolism of the cardinal points, teach about its importance, and frequently use it in the ritual setting. Other respect the significance of the cardinal points in the sense that they are related to elements they are asking for help, so they pay tribute to them at the very beginning of every ceremony but use them quite rarely in the ritual. On the opposite side of the scale is the altar in FSS seminars which does not emphasize the cardinal points at all. The altar is perceived as a 'shamanic axis mundi', a place of power indifferent to elements of the cardinal points. 
ture that all my informants agreed on independently is the concentration and mental effort with which they perform the ritual.

In my point of view a ritual is an activity you do consciously and with intention. [...] I think the inevitable part of a ritual is the faith and belief in what you're doing... when you push the energy into it. When you don't do that, it doesn't matter what you do - nothing's gonna happen. Informant C, 15/10/2017

Contemporary shamans respect the formal side of the ritual mostly by heeding the importance of the formal repetition. The ritualization can accumulate energy and "it is easier to walk the familiar paths" (Informant B, 13/10/2017). Moreover, the ritual "helps clients accept the shamanic treatment" (Informant E, 22/05/2017) since it creates new space for experiencing the illness. As anthropologist Mary Douglas puts it: "[Ritual] can come first in formulating experience. It can permit knowledge of what would otherwise not be known at all. It does not merely externalise experience, [...] but it modifies experience in so expressing it" (Douglas 1966: 65).

The certain symbolical vagueness of the ritual performance in a structured ritual space, combined with the emphasis on one's own personal involvement, gives every participant the opportunity to become the central component of the ritual's functionality. Each participant can realize the nature of their illness or misfortune, find their power animal in a nonordinary reality and ask them for help and guidance, or create a unique image of this world by engaging their own imagination - be it visual, acoustic or kinetic (Csordas 1994: 74).

These experiences were always fully respected by the shaman leading the seminar and taken seriously by the other participants. An important shamanic role is supporting the client in locating their predicament and assisting in finding an assumption, visualization and treatment. As Galina Lindquist puts it, the ritual provides "an archaeology of memory that the shaman and the patient are exploring together" (2004: 163). Before the ritual is brought to an end, participants are encouraged to share their experiences, but to refrain from a 'secondary rational analysis'. Neither the shaman himself nor the participants have the right to analyze somebody else's experience.

As a result, "a safe space for listening, accepting and respecting" (Informant F, 22/04/2017) is created during the shamanic seminars. This mindset therefore allows for the creation of a spontaneous communitas 
(Turner 1969) or, as contemporary shamans put it, the community in which we all originally lived, thanks to which all the participants of 'neoshamanic' sessions can experience a feeling of safety, togetherness, and a deep sense of unity with each other (Informant C, 15/10/2017). In summary, on the one hand, these gatherings enable participants to create new contexts for their problems and to be respected during the experience. On the other, its elusive volatility does not bring any community-creating consequences and responsibilities.

\section{Conclusion}

Many academic papers, books and articles have argued that the very embedded concept of 'shamanism' is a mere western construction, ${ }^{8}$ projection or imagination of idyllic primitive societies influenced by the romantic fascination with the noble savage (Noel 1997; Stuckrad 2002 and 2003; Znamenski 2007; and Boekhoven 2011). This discursive tradition of understanding shamanism as a form of a synchronic archaic tradition extending across the whole of the primitive world (Hutton 2001: 113-128) has been supported by historians of religion such as Mircea Eliade (1964) and anthropologists such as Carlos Castaneda $(1968 ; 1972 ; 1977)$ and Michael Harner (1980).

Nevertheless, these romanticizing pictures of the 'ancient spirituality' of shamanism are not unique. Moreover, they bear many similarities to other current spiritual trends. ${ }^{9}$ This longing for a life in harmony with nature, in a community of mutual trust and respect, with an opportunity to perform spiritual work providing health and emotional satisfaction essentially converges with other forms of postmodern spirituality.

In the case of contemporary Czech shamanism, the pervasive references to the symbolism of 'the original inhabitants of Mother Earth' are omnipresent: the choice of well-known 'traditional' rituals, the selection of 'traditional' herbs, the aesthetic of the altar and also the attempt to create the respectful atmosphere of the 'first unsullied communities'. Nevertheless, it seems that the originality of shamanism does not play a great role in the explanatory part of shamanic seminars. The significance of the natural and ancient origins of shamanism primarily becomes apparent in experiencing the ritual, for example, in the imagining of the shamanic visions.

8 For a critique of the academic construction of "shamanism", see Taussig (1991) or Kehoe (2000).

9 In the 'New Age' environment, the faith in an esoteric ancient truth is quite common. The carriers of the wisdom are diverse: from Mayas to Atlanteans, from shamans of the Amazonian rainforest to Celtic herbalists. 
This implicit symbolical acceptance is perceived in such a way that shamanism is an original component of all the world's religions, an interpretative key to reality, and an unspoiled spirituality which is opposed to other institutionalized forms of religion, but not to the exclusion of them. From the shamanic point of view, many other techniques are deemed to be ancient, unstructured and spontaneous, and therefore they are considered to be true and authentic spirituality (Crockford 2010: 147). By means of this eclecticism and the acceptance of an infinite number of varieties of spirituality an individual religiosity is created.

Although shamanism allows the individual employment of shamanic techniques, it also has many rituals (especially healing ones) at its disposal. With regard to the importance of the spontaneous communitas, many regular participants of the shamanic seminars visit them precisely for this reason and many collective rituals are held throughout the year (winter/summer solstice, regular sweat lodges, vision quests, collective prayers for concrete landscapes, helping dead souls to find their way out of this world...etc.)

If we assume that well-elaborated ritual practice plays pivotal role in current Czech shamanism, let us consider the preconditions for its success. According to the outcomes of my field research, they are two-fold:

Firstly, current shamanism operates with a broader definition of illness and it heals even in cases which current western biomedicine ignores (psychosomatics), cannot cure (final cancer stages) or does not even consider an illness (loss of the soul). Nevertheless, current shamanism does not treat the causes of illness exclusively, but is open to cooperation with traditional western medicine and psychotherapy. Contemporary shamans thus deal with a whole range of illnesses (from physical to spiritual), while respecting the autodiagnosis that allows them to take the metaphorical and symbolical explications of their clients seriously. As a consequence, this provides a creative space for both the types of experience (kinetic, acoustic, visual) and the types of description (a symbolic scene, a story, a feeling).

Shamans let their clients understand their problem, formulate it, and experience it. The clients can focus their attention on this problem, which helps them see the solution that fits their own understanding of the causes and consequences of the problem. With the power of this concentration, supported by the shared visualization of the other participants, shamans believe everyone can change the material reality and therefore achieve a balance and reconnection with the divine energy of this universe, and thus recover. As a consequence, shamanic techniques 
are often used in private life as a psychotherapeutic and self-knowing instrument, because the shamanic practice appeals to psychical development: knowing yourself is a precondition for treatment.

Secondly, contemporary shamanism gives its practitioners the opportunity to act ritually in the context of the Czech religious environment, where it is problematic to act ritually for several reasons. The first of theses is that Czechs feel an instinctive historically based distrust of institutionalized forms of religion in which ritualization is more commonly found (for example, in the Catholic mass). Nevertheless, current shamanism with its ritualistic framework has established itself in the contemporary Czech religious area as both an 'authentic' and 'original' practice of those mythical primordial societies that lived in harmony with the whole world and which are worth following and imitating. Shamanism is perceived as an 'authentic' spirituality, as a technique, and not as a religion - regardless of how we, as scholars, define these concepts.

Another reason is that shamanism provides an opportunity to act ritually in the rather individualistic environment of modern western spirituality. Many participants of shamanic courses visit other spiritdeveloping seminars focused on 'the divine Self', the inner Goddess or individual spiritual growth (Hanegraaff 1996), but they keep returning back to the experience of the sense of spontaneus communitas in collective ritual practice or individual healing rituals.

In conclusion, it can be argued that current Czech shamanism is very similar to modern western spirituality on the declarative level: in its use of the concept of cosmic energy, in similarities in the theodicy and in stressing the importance of individual experience. On the other hand, by constantly referring to the connection and kinship to traditional shamanism, current shamanism creates room for accepting 'authentic' and 'natural' ritual formalization, which helps to heal illness, misfortune and non-functional relationships.

Contemporary Czech shamanism thus charts a delicate path between the Scylla of being labelled as a 'religion' and the Charybdis of being absorbed by modern western spirituality or remaining apart unnoticed. As a result, it can define its own unique identity while being immune from typical Czech stigmatization of 'mere rigid ritualization'.

March 2020 


\section{Bibliography}

Boekhoven, Jeroen W. 2011. Genealogies of Shamanism: Struggles for Power, Charisma and Authority. Groningen: Barkhuis.

Bužeková Tatiana. 2010. The Shaman's Journey between Emic and Etic: Representation of the Shaman in Neo-Shamanism. Anthropological Journal of European Cultures 19, 1: 116-130.

Bužeková, Tatiana. 2019. Shamanic Gift in the Global Village: Spiritual Energy and Biomedicine. Slovenský národopis 64, 4: 412-429.

Castaneda, Carlos. 1968. The Teachings of Don Juan: A Yaqui Way of Knowledge. Berkeley: University of California Press.

Castaneda, Carlos. 1972. The fourney to Ixtlan: Further Conversations with Don fuan. New York: Simon \& Schuster.

Castaneda, Carlos. 1977. The Second Ring of Power. New York: Simon \& Schuster.

Crockford, Susannah. 2010. Shamanisms and the Authenticity of Religious Experience. The Pomegranate 12, 2: 139-158.

Csordas, Thomas. 1994. The Sacred Self: A cultural Phenomenology of Charismatic Healing. Berkeley: University of California Press.

Douglas, Mary. 1966. Purity and Danger: An Analysis of concepts of pollution and taboo. London: Routledge.

Eliade, Mircea. 1964. Shamanism: Archaic Techniques of Ecstasy. Princeton: Princeton University Press.

Exnerová, Helena. 2018. Český šamanismus v rozhovorech. Praha: Dingir.

Hamplová Dana. 2013. Náboženství v české společnosti na prahu 3. tisíciletí. Praha: Karolinum.

Hanegraaff, Wouter. 1996. New Age Religion and Western Culture: Esotericism in the Mirror of Secular Thought. Leiden: Brill.

Harner, Michael. 1980. The Way of the Shaman: A Guide to Power and Healing. San Francisco: Harper \& Row.

Horák, Miroslav - Vosáhlová, Šárka. 2016. Tradiční amazonská medicína v české subkultuře. Anthropologia Integra 7, 2: 47-55.

Horák, Miroslav. 2017. Ayahuasca v České republice. Brno: Mendelova univerzita v Brně.

Hutton, Roland. 2001. Shamans: Siberian Spirituality and the Western Imagination. London: Hambledon Continuum.

Jakobsen, Merete Demant. 1999. Shamanism: Traditional and Contemporary Approaches to the Mastery of Spirits and Healing. New York: Berghahn books.

Kehoe, Alice Beck. 2000. Shamans and Religion: An Anthropological Exploration in Critical Thinking. Long Grove: Waveland Press. 
Kleinman, Arthur. 1962. The Illness Narratives. New York, Basic Books.

Kostićová, Zuzana Marie. 2019. Nenáboženská spiritualita jako (náboženský) diskurz. Dingir: religionistický časopis o současné náboženské scéně 22, 3: 74-76.

Lindquist, Galina. 1997. Shamanic Performance of the Urban Scene: NeoShamanism in Contemporary Sweden. Stockholm: Stockholm Studies in Social Anthropology.

Lindquist, Galina. 2004. Bringing the Soul Back to the Self: Soul Retrieval in Neo-Shamanism. Social Analysis: The International fournal of Social and Cultural Practice 48, 2: 157-173.

Lombardi, Denise. 2010. Neo-Chamanismo: el ritual transferido. An unpublished conference paper presented at "XI Coloquio Internacional sobre Otopames", Tlaxcala. [online] [2020-0518] Retrieved from: https://www.academia.edu/10303152/Neochamanismo_el_ritual_transferido

Lužný, Dušan. 1994. Neošamanismus - postmoderní techniky extáze. K problematice náboženství v dnešní době. Religio 3, 1: 169-180.

Nešpor, Zdeněk - Nešporová, Olga. 2009. Religion: An Unsolved Problem for the Modern Czech Nation. Czech Sociological Review 45, 6: 1215-1237.

Noel, Daniel C. 1997. The Soul of Shaman: Western Fantasies, Imaginal Realities. New York: Continuum.

Pharo, Kirkhusmo Lars. 2011. A Methodology for a Deconstruction and Reconstruction of the Concepts 'Shaman' and 'Shamanism'. Numen 58: 6-70.

Stuckrad, Kocku von. 2002. Reenchanting Nature: Modern Western Shamanism and Nineteenth-Century Thought. Fournal of American Academy of Religion 70: 771-799.

Stuckrad, Kocku von. 2003. Schamanismus und Esoterik: Kultur- und wissenschaftliche Betrachtungen. Leuven: Peeters.

Stuckrad, Kocku von. 2015. The Scientification of Religion: An Historical Study of Discursive Change 1800-2000. Boston - Berlin: De Gruyter.

Taussig, Michael. 1991. Shamanism, Colonialism, and the Wild Man: A Study in Terror and Healing. Chicago: The University of Chicago Press.

Turner, Victor. 1969. The Ritual Process: Structure and Anti-Structure by Victor Turner. New York: De Gruyter.

Vencálek, Matouš. 2017. Religious, Socio-cultural and Political Worldviews of Contemporary Pagans in the Czech Republic. Pomegranate: The International fournal of Pagan Studies 19, 2: 233-250.

Vojtíšek, Zdeněk. 2004. Encyklopedie náboženských směrů a hnutí v České republice: náboženství, tradice, církve, sekty, duchovní společenství. Praha: Portál. 
Vojtíšek, Zdeněk. 2007. Novopohanstvo - živenie mŕtvej tradície (4). Rozmer: časopis pre krestanskú duchovnú orientáciu 1: 30-34.

Wallis, Robert J. 2000. Queer Shamans: Autoarchaeology and NeoShamanism. World Archaeology 32, 2: 252-262.

Wallis, Robert J. 2003. Shamans/Neo-Shamans: Ecstasy, Alternative Archaeologies and Contemporary Pagans. London and New York: Routledge.

Weber, Max. 1914. Wirtschaft und Gesellschaft. Tübingen: J.C.B. Mohr.

Wilson, David Gordon. 2013. Redefining Shamanism: Spiritual Mediums, and Other Traditional Shamans as Apprenticeship Outcomes. London: Bloomsbury.

Znamenski, Andrei A. 2007. The Beauty of the Primitive: Shamanism and the Western Imagination. Oxford: Oxford University Press. 